\title{
Fitoremediasi Limbah Radioaktif Cair Menggunakan Kayu Apu (Pistia stratiotes) untuk Menurunkan Kadar Torium
}

\section{Phytoremediation of Liquid Radioactive Waste Using Apu Wood (Pistia stratiotes) to Reduce Thorium Contents}

\author{
Prima Soheti $^{1 *}$, La Ode Sumarlin ${ }^{1}$, Dany Poltak Marisi ${ }^{2}$ \\ ${ }^{1}$ Jurusan Kimia, Fakultas Sains dan Teknologi, Universitas Islam Negeri Syarif Hidayatullah Jakarta, \\ Jl. Ir H. Juanda No. 95, Tangerang Selatan 15412 \\ ${ }^{2}$ Pusat Teknologi Bahan Galian Nuklir-BATAN \\ J1. Lebak Bulus Raya No.9, Pasar Jumat, Jakarta, Indonesia, 12440 \\ *E-Mail: sohetiprima@gmail.com
}

Naskah diterima: 10 November 2020, direvisi: 20 November 2020, disetujui: 23 November 2020

DOI: 10.17146/eksplorium.2020.41.2.6092

\begin{abstract}
ABSTRAK
Limbah torium (Th) merupakan limbah radioaktif pemancar alfa yang berbahaya bagi lingkungan dan makhluk hidup sehingga perlu dilakukan pengolahan limbah yang efektif dengan fitoremediasi. Fitoremediasi adalah kemampuan tumbuhan untuk mengurangi bahan pencemar yang ada dalam lingkungan. Tujuan penelitian adalah menguji kemampuan tumbuhan kayu apu dalam menurunkan kadar Th dari limbah yang terkontaminasi Th. Kadar Th pada tumbuhan kayu apu dan limbah cair dianalisis dengan Spektrofotometer UV-VIS sementara radioaktivitasnya diukur dengan Ludlum Model 1000 Scaler. Parameter terjadinya fitoremediasi antara lain kondisi fisik tumbuhan yang menurun, $\mathrm{pH}$ limbah yang mendekati netral, dan suhu yang fluktuatif mengikuti suhu lingkungan. Hasil penelitian menunjukkan biomassa tumbuhan kayu apu mengalami penurunan setelah fitoremediasi menjadi 96,2\% dengan efisiensi remediasi sebesar 97,4\% dari konsentrasi awal limbah radioaktif cair Th sebesar 10 ppm. Hal ini disebabkan karena terjadinya penyerapan Th sehingga mengakibatkan akumulasi Th pada tumbuhan kayu apu sebesar 4069,4 mg/kg. Tumbuhan kayu apu juga mampu menurunkan radioaktivitas limbah cair Th menjadi 0,631 Bq/L dari radioaktivitas awal sebesar 2,819 Bq/L. Tingkat radioaktivitas sudah di bawah Tingkat Klierens dan limbah dapat dilepas ke lingkungan dengan aman.
\end{abstract}

Kata kunci: fitoremediasi, torium, limbah radioaktif cair, Pistia stratiotes

\begin{abstract}
Thorium (Th) waste is an alpha-emitting radioactive waste that is harmful to the environment and living things so it is necessary to treat the waste effectively with phytoremediation. Phytoremediation is a plant ability to reduce pollutants presence in the environment. This research aim is examining apu wood plant ability to reduce Th contents from Th-contaminated waste. The UV-VIS spectrophotometer analysed Th level in apu wood plant and liquid waste while the Ludlum Model 1000 Scaler measured their radioactivity. The parameters for phytoremediation occurrence include the decreasing physical condition of the plants, the pH of the waste that is close to neutral, and the temperature that fluctuates with the ambient temperature. The results showed that the plant biomass of apu wood decreased after phytoremediation to $96.2 \%$ with a remediation efficiency of $97.4 \%$ from the initial concentration of Th liquid radioactive waste of 10 ppm. This is due to thorium absorption resulting in thorium accumulation in apu wood plants of 4,069.4 $\mathrm{mg} / \mathrm{kg}$. Apu wood was also able to reduce Th liquid waste radioactivity to $0.631 \mathrm{~Bq} / \mathrm{L}$ from the initial radioactivity of $2.819 \mathrm{~Bq} / \mathrm{L}$. The radioactivity level is below the Klierens Level and it is safe to release the waste into the environment.
\end{abstract}

Keywords: Phytoremediation, thorium, liquid radioactive waste, Pistia stratiotes 


\section{PENDAHULUAN}

Limbah cair yang mengandung torium (Th) mempunyai waktu paruh panjang dan bersifat radioaktif sehingga dapat menyebabkan efek radiasi yang merusak gen dan sel tubuh makhluk hidup apabila terpapar [1]. Efek radiasi dapat berupa efek deterministik dan efek stokastik. Efek deterministik yaitu efek yang keparahannya akan semakin meningkat seiring meningkatnya dosis yang diterima. Efek ini muncul apabila ambang dosis terlampaui sehingga akan mengakibatkan beberapa dampak seperti pengelupasan kulit (eritema), luka bakar, katarak, dan kemandulan. Pada efek stokastik, jumlah dosis radiasi tidak mempengaruhi tingkat keparahan tetapi mempengaruhi kemungkinan timbul efek tersebut seperti kanker dan leukemia [2].

Limbah cair torium memiliki berbagai dampak berbahaya sehingga diperlukan pengolahan agar aman bagi lingkungan. Pengolahan limbah cair dapat dilakukan dengan metode fisika, kimia, dan biologi. Salah satu contoh proses pengolahan limbah cair monasit melalui cara kimia yaitu koagulasi secara optimal menggunakan koagulan fero sulfat dengan dosis $225 \mathrm{mg} / \mathrm{L}$ dan $\mathrm{pH}$ 8,0. Metode tersebut dapat menurunkan kadar torium $45,20 \%$ dan radioaktivitas hingga $100 \%$ [3]. Pengolahan limbah cair secara fisika dapat dilakukan menggunakan resin penukar ion. Penggunaan resin penukar ion amberlite IRA-400 $\mathrm{Cl}$ pada penyerapan uranium dalam bentuk uranil karbonat dapat memberikan hasil optimum pada komposisi berat umpan $\mathrm{U} / \mathrm{Na}_{2} \mathrm{CO}_{3}$ sebesar 0,025 dengan waktu kontak 80 menit dan menghasilkan efisiensi penyerapan 65,78\% [4].

Pengolahan limbah cair dengan menggunakan bahan kimia berpotensi menimbulkan pencemaran lingkungan karena hasil pengolahan kimia pada limbah masih sedikit mengandung logam berat dan zat padat terlarut sehingga belum dapat dibuang ke lingkungan. Sedangkan pengolahan limbah cair secara fisika memerlukan biaya yang cukup mahal dan tidak cukup efektif untuk memindahkan kontaminan dalam air [5]. Oleh karena itu, diperlukan upaya pengembangan metode pengolahan limbah alternatif yang lebih efektif dan efisien, salah satunya secara biologi, yaitu dengan fitoremediasi.

Fitoremediasi merupakan salah satu cara pengolahan limbah baik padat maupun cair menggunakan tumbuhan sebagai agen biologi dalam pengolahan limbah [6]. Keuntungan fitoremediasi dibandingkan dengan metode pengolahan limbah lainnya adalah proses pengolahan dapat dilakukan secara insitu dan eksitu sehingga mudah diterapkan dan tidak memerlukan biaya tinggi. Fitoremediasi juga dapat bekerja pada senyawa organik dan anorganik serta dapat mereduksi kontaminan dalam jumlah yang besar. Selain itu, fitoremediasi juga merupakan metode pengolahan limbah yang ramah lingkungan [7].

Fitoremediasi umumnya menggunakan tumbuhan yang bersifat hiperakumulator. Tumbuhan hiperakumulator memiliki tingkat laju penyerapan dan translokasi logam seratus kali lebih tinggi dibandingkan dengan tumbuhan normal saat mengalami penurunan produksi dan keracunan logam [8]. Tumbuhan hiperakumulator yang sering dimanfaatkan adalah tumbuhan non pangan dan banyak ditemukan di alam seperti kayu apu (Pistia stratiotes) (Gambar 1) [9].

Penelitian terdahulu menunjukkan bahwa proses fitoremediasi pada tumbuhan hiperakumulator seperti kayu apu dapat menurunkan logam berat $\mathrm{Cu}$ pada konsentrasi 
2 ppm sebesar $94 \%$ dan 5 ppm sebesar $90 \%$ [9]. Reaktor uji dengan enam tumbuhan kayu apu di dalamnya mampu menyisihkan total $\mathrm{Cr}$ sebesar 95,01\% [10]. Kayu apu seberat 500 g/6 L juga mampu menurunkan kadar $\mathrm{Hg}$ sebesar 77,6\% [11].

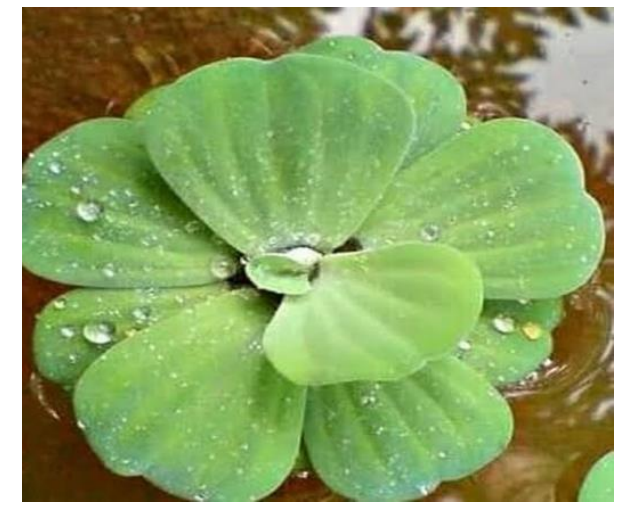

Gambar 1. Tanaman kayu apu (Pistia stratiotes).

Penelitian fitoremediasi menggunakan tumbuhan kayu apu untuk menurunkan kadar logam radioaktif seperti torium pada limbah cair belum pernah dilakukan. Pada penelitian ini dilakukan fitoremediasi limbah radioaktif cair dengan menggunakan kayu apu (Pistia stratiotes) untuk melihat efektifitas kayu apu dalam menurunkan kadar torium. Paramater yang diteliti meliputi kadar torium dan radioaktivitasnya, kondisi fisik tumbuhan, $\mathrm{pH}$ dan suhu pada air limbah sebelum dan sesudah fitoremediasi, serta berat tumbuhan dan penyerapan torium pada awal dan akhir penelitian.

\section{METODOLOGI}

\section{Alat dan Bahan}

Alat yang digunakan pada penelitian ini antara lain neraca analitik (Sartorius seri BSA2245-CW), oven furnace (Ney seri Vulcan D-550), magnetic stirrer (MaxBlend seri MP-6RS), Ludlum Model 1000 Scaler, Spektrofotometer UV-Vis (Hitachi seri U2900), pH meter (Metrohm seri 69I), beaker glass, corong, batang pengaduk, cawan porselen, cawan petri, kertas saring whattman, pipet tetes, pipet volume, pipet gondok, gelas teflon, planset, botol sampel, hot plate, labu ukur, thermometer, mortar, dan desikator. Bahan yang digunakan berupa tumbuhan kayu apu yang diperoleh dari Kolam Sub Bidang Pengelolaan Limbah Pusat Teknologi Bahan Galian Nuklir (PTBGN-BATAN), padatan torium nitrat p.a, aquades, larutan asam nitrat : asam perklorat (1:6) p.a, larutan asam askorbat 5\% (b/v) p.a, larutan torin p.a, larutan asam klorida $\mathrm{pH} 0,8$ p.a, larutan larutan asam sulfat p.a, dan larutan asam klorida p.a.

\section{Preparasi Limbah Radioaktif Cair Torium}

Larutan induk torium dibuat dengan menimbang 2,4574 g padatan torium nitrat dalam labu ukur $100 \mathrm{~mL}$. Larutan induk torium $10.000 \mathrm{ppm}$ kemudian diencerkan menjadi 1.000 ppm. Larutan induk 1.000 ppm diambil sebanyak $3,5,10$, dan $15 \mathrm{~mL}$ dalam $1000 \mathrm{~mL}$ hingga konsentrasinya menjadi 3, 5, 10, dan $15 \mathrm{ppm}$. Proses preparasi limbah radioaktif cair torium dilakukan dengan alat pelindung diri (APD) sesuai dengan Standar Keselamatan Kerja dan Proteksi Radiasi BATAN [12].

\section{Aklimatisasi Tumbuhan}

Aklimatisasi tumbuhan dilakukan dengan cara mengambil tumbuhan kayu apu yang kondisinya baik dari kolam. Tumbuhan kayu apu kemudian dibersihkan dari kotoran atau lumpur yang menempel, selanjutnya diaklimatisasi dengan air sumur dalam wadah selama 7 hari [13].

\section{Range Finding Test}

Range Finding Test (RFT) adalah tes penemuan rentang konsentrasi optimal yang tidak memberi efek kematian pada tumbuhan. Konsentrasi optimal ditunjukkan dengan tidak terjadinya perubahan fisik tumbuhan (warna 
daun). Pengujian dilakukan selama 7 hari karena dalam waktu 7 hari tumbuhan sudah mampu menyerap logam secara optimal sesuai dengan kemampuan fitoremediasi tumbuhan kayu apu. Berat tumbuhan kayu apu yang digunakan sekitar 5-15 g. Pengujian dilakukan secara duplo pada konsentrasi 3, 5, 10, $15 \mathrm{ppm}$ torium dalam $250 \mathrm{~mL}$ limbah cair [9].

\section{Penetapan Radioaktivitas}

Penetapan radioaktivitas pada limbah cair dilakukan sebelum dan sesudah fitoremediasi. Sampel berupa limbah cair sebanyak $500 \mathrm{~mL}$ dikisatkan menjadi $100 \mathrm{~mL}$ kemudian dipindahkan ke beaker glass dan diuapkan hingga terbentuk pasta. Pasta tersebut kemudian dipindahkan ke planset hingga kering dan didinginkan di dalam desikator. Radioaktivitas kemudian diukur dengan dengan Ludlum Model 1000 Scaler [14]. Radioaktivitas dihitung dengan menggunakan rumus:

$$
A=\frac{r_{s}-r_{o}}{\mathrm{t}}:(\varepsilon \times v)
$$

Parameter A merupakan aktivitas dari sumber radioaktif (dalam Becquerel), $\mathbf{r}_{\mathbf{s}}$ adalah laju cacah total cuplikan (cacah/menit), $\mathbf{r}_{\mathbf{o}}$ adalah laju cacah total latar (cacah/menit), $\mathbf{t}$ adalah waktu cacahan (detik), $\boldsymbol{\varepsilon}$ adalah efisiensi pencacahan sumber kalibrasi tertentu, dan $\mathbf{v}$ adalah volume sampel (liter).

\section{Fitoremediasi}

Fitoremediasi dilakukan dengan memasukkan limbah cair dan tumbuhan kayu apu ke dalam reaktor. Proses ini dilakukan di 2 reaktor uji, yaitu reaktor kontrol dan reaktor fitoremediasi (uji) (Tabel 1). Reaktor kontrol menggunakan air sumur sebagai kontrol, sedangkan reaktor fitoremediasi (uji) menggunakan air limbah radioaktif dengan konsentrasi optimal sesuai hasil RFT sebagai reaktor uji. Pengambilan sampel limbah cair, pengamatan kondisi fisik tumbuhan kayu apu, serta pengukuran $\mathrm{pH}$ dan suhu dilakukan secara duplo selama 15 hari dengan selang waktu 3 hari [15].

Tabel 1. Tahap pengujian fitoremediasi kayu apu.

\begin{tabular}{cccc}
\hline Reaktor & $\begin{array}{c}\text { Berat Kayu } \\
\text { Apu (g) }\end{array}$ & $\begin{array}{c}\text { Media } \\
\text { Tumbuh }\end{array}$ & $\begin{array}{c}\text { Volume } \\
(\mathbf{m L})\end{array}$ \\
\hline Kontrol & $5-15 \mathrm{~g}$ & Air Sumur & 1.000 \\
$\begin{array}{c}\text { Fitoremediasi } \\
\text { (Uji) }\end{array}$ & $5-15 \mathrm{~g}$ & $\begin{array}{c}\text { Limbah } \\
\text { Radioaktif } \\
\text { Cair }\end{array}$ & 1.000 \\
\hline
\end{tabular}

\section{Leaching Sampel Tumbuhan}

Kadar torium pada tumbuhan diukur dengan melakukan pelarutan (leaching) terhadap sampel tumbuhan terlebih dahulu. Sampel tumbuhan kering yang sudah digerus halus ditimbang sebanyak 1 gram dan dimasukkan ke gelas Teflon kemudian ditambahkan masing-masing $20 \mathrm{~mL}$ asam campur yaitu $\mathrm{HNO}_{3}$ dan $\mathrm{HClO}_{4}$ dengan perbandingan 1:6. Campuran tersebut kemudian dipanaskan selama \pm 2 jam sampai terbentuk pasta. Larutan $\mathrm{H}_{2} \mathrm{SO}_{4}$ sebanyak 15 mL ditambahkan ke dalam pasta kemudian dipanaskan lagi hingga kering. Setelah kering, pasta dilarutkan dengan $\mathrm{HCl}$ dan dipindahkan ke labu ukur $50 \mathrm{~mL}$ dan ditepatkan sampai tanda garis dengan $\mathrm{HCl}$. Sampel cair diukur dengan metode penetapan torium menggunakan Spektrofotometer UVVIS [16].

\section{Penetapan Torium dengan Metode Spektrofotometer UV-Vis}

Larutan sampel masing-masing dipipet sebanyak $10 \mathrm{~mL}$ ke dalam labu ukur $50 \mathrm{~mL}$. Larutan kemudian ditambahkan dengan $5 \mathrm{~mL}$ asam askorbat 5\% (b/v) dan dikocok, lalu ditambahkan $5 \mathrm{~mL}$ torin. Labu ukur 
ditepatkan volumenya dengan $\mathrm{HCl} \mathrm{pH} 0,8$. Sampel dibiarkan selama 30 menit hingga stabil. Larutan kompleks yang telah stabil diukur absorbansinya dengan menggunakan Spektrofotometer UV-Vis pada panjang gelombang $545 \mathrm{~nm}$ [16].

\section{Penetapan Biomassa}

Produksi biomassa (BM) dalam satuan persen dipengaruhi oleh faktor berat sampel basah dalam gram (A) dan berat sampel kering setelah pengeringan pada suhu $105^{\circ} \mathrm{C}$ selama 6 jam (B). Biomassa dihitung dengan menggunakan rumus yang mengacu pada metode SNI 13-6793-2002 [17] yaitu :

$$
B M=\frac{\mathrm{A}-\mathrm{B}}{\mathrm{A}} \chi 100 \%
$$

\section{Penetapan Efisiensi Remediasi Torium oleh Tumbuhan}

Efisiensi Remediasi Torium (EF) merupakan hubungan selisih antara konsentrasi torium sebelum fitoremediasi $\left(\mathrm{C}_{\text {awal }}\right)$ dan konsentrasi torium setelah fitoremediasi $\left(\mathrm{C}_{\mathrm{akhir}}\right)$ dengan konsentrasi torium sebelum fitoremediasi $\left(\mathrm{C}_{\text {awal }}\right)$. Efisiensi Remediasi Torium (EF) dapat dihitung dengan persamaan (3), yaitu :

$$
E F=\frac{C_{a w a l}-C_{a k h i r}}{C_{\text {awal }}} \times 100 \%
$$

\section{HASIL DAN PEMBAHASAN Fitoremediasi}

Hasil penelitian menunjukkan bahwa kayu apu mampu tumbuh dengan baik pada konsentrasi 3, 5, dan 10 ppm (Tabel 2). Hal ini ditandai dengan tumbuhan yang masih berwarna hijau segar setelah 7 hari pemaparan. Pada konsentrasi 15 ppm, tumbuhan ini kurang mampu tumbuh dengan baik, ditandai dengan tepi daun berwarna kuning kecoklatan. Pengujian RFT yang dilakukan secara duplo menunjukkan hasil pengamatan yang sama. Konsentrasi optimal logam torium pada kayu apu adalah 10 ppm. Konsentrasi optimal RFT ditunjukkan dengan tidak adanya perubahan fisik (warna daun) pada tumbuhan [18].

Tabel 2. Hasil pengujian RFT kayu apu.

\begin{tabular}{lllcc}
\hline Konsentrasi & Pengamatan Awal & Pengamatan Akhir & Keterangan & $\begin{array}{c}\text { Jumlah } \\
\text { Sampel }\end{array}$ \\
\hline Kontrol & Tumbuhan hijau segar & Tumbuhan hijau segar & Hidup & 2 \\
$3 \mathrm{ppm}$ & Tumbuhan hijau segar & Tumbuhan hijau segar & Hidup & 2 \\
$5 \mathrm{ppm}$ & Tumbuhan hijau segar & Tumbuhan hijau segar & Hidup & 2 \\
$10 \mathrm{ppm}$ & Tumbuhan hijau segar & Tumbuhan hijau segar & Hidup & 2 \\
$15 \mathrm{ppm}$ & Tumbuhan hijau segar & Tepi daun berwana & Hidup & 2 \\
& & kuning kecoklatan & & \\
\hline
\end{tabular}

Hasil ini sesuai dengan penelitian yang menjelaskan bahwa kayu apu mampu tumbuh dan menyerap logam berat $\mathrm{Cu}$ dengan baik pada konsentrasi logam $\mathrm{Cu}$ sebesar 10 ppm [19]. Konsentrasi limbah radioaktif cair torium sebesar 10 ppm kemudian digunakan pada proses fitoremediasi.

Perubahan fisik merupakan respon tumbuhan terhadap logam yang menunjukkan kemampuan adaptasi terhadap logam [20].
Pengamatan fisik yang dilakukan secara duplo pada fitoremediasi oleh kayu apu menunjukkan hasil yang sama. Pada hari ke-0 hingga 6 , tumbuhan kayu apu masih terlihat segar atau daunnya masih terlihat hijau, namun pada hari ke-9 tumbuhan yang berada pada reaktor limbah radioaktif cair torium mulai menunjukkan gejala klorosis yaitu daun yang semula hijau beubah menjadi kuning kecoklatan (Tabel 3 dan Gambar 2). Kondisi 
serupa terjadi pada tumbuhan kayu apu dalam air sumur yang mengandung logam Fe. Pada awal penelitian hingga hari ke-7 kondisi fisik tumbuhan masih segar, namun kemudian terus menurun hingga hari ke-14 [20].

Tabel 3. Pengamatan fisik kayu apu.

\begin{tabular}{ccc}
\hline $\begin{array}{c}\text { Waktu } \\
\text { Pemaparan } \\
\text { (Hari) }\end{array}$ & Kayu Apu & $\begin{array}{c}\text { Jumlah } \\
\text { Sampel } \\
\text { (n) }\end{array}$ \\
\hline 0 & Tumbuhan hijau segar & 2 \\
3 & Tumbuhan hijau segar & 2 \\
6 & Tumbuhan hijau segar & 2 \\
9 & $\begin{array}{c}\text { Daun kuning } \\
\text { kecoklatan } \\
\text { Daun kuning } \\
\text { kecoklatan }\end{array}$ & 2 \\
12 & $\begin{array}{c}\text { Daun kuning } \\
\text { kecoklatan }\end{array}$ & 2 \\
\hline
\end{tabular}

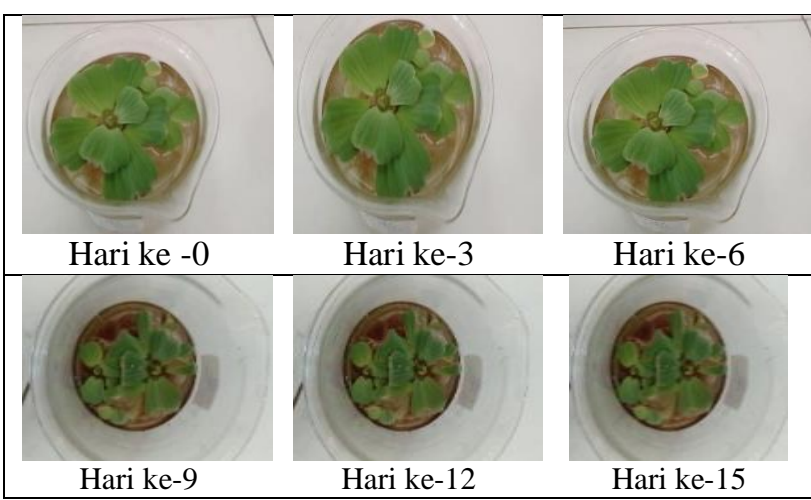

Gambar 2. Perubahan fisik kayu apu selama proses fitoremediasi.

Pada proses fitoremediasi, tumbuhan bertahan hidup dengan menyerap radionuklida baik dalam media asam atau alkali dan memiliki kecenderungan untuk mengubah pH menuju netral [21]. Pengukuran pH dilakukan secara duplo $(n=2)$ pada reaktor kontrol maupun reaktor uji dan diperoleh nilai standar deviasi (SD) sebesar \pm 0,0070 .

Nilai $\mathrm{pH}$ pada tumbuhan kayu apu dalam proses fitoremediasi mengalami peningkatan (Gambar 3) seiring bertambahnya waktu running pada reaktor penelitian. Nilai $\mathrm{pH}$ tumbuhan kayu apu pada proses fitoremediasi meningkat dari 3,36 (SD $\pm 0,0070)$ menjadi
$6,76$ (SD $\pm 0,0070)$. Nilai $\mathrm{pH}$ yang meningkat dapat menurunkan kelarutan oksigen dalam air dan meningkatkan toksisitas logam [22]. Peningkatan nilai $\mathrm{pH}$ disebabkan oleh proses fotosintesis yang menghasilkan $\mathrm{O}_{2}$ dan melepas ion $\mathrm{OH}^{-}$ke dalam air serta mengambil ion $\mathrm{H}^{+}$yang terdapat pada air [23]. Reaksi fotosintesis (4) adalah sebagai berikut [24]:

$$
6 \mathrm{CO}_{2}+6 \mathrm{H}_{2} \mathrm{O} \underset{\text { Klorofil }}{\stackrel{\text { Cahaya }}{\longrightarrow}} \mathrm{C}_{6} \mathrm{H}_{12} \mathrm{O}_{6}+6 \mathrm{O}_{2}
$$

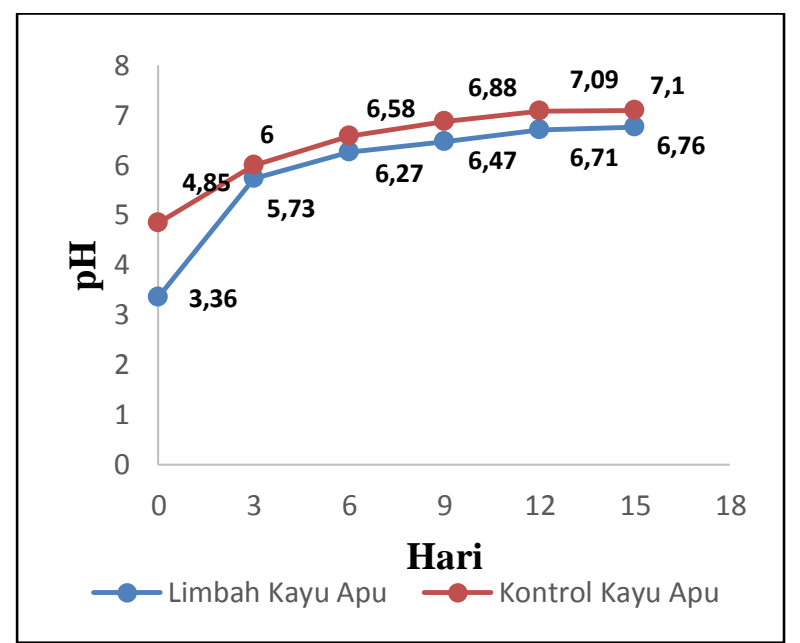

Gambar 3. Perubahan $\mathrm{pH}$ selama proses fitoremediasi menggunakan kayu apu.

Reaksi fotosintesis yang terjadi pada tumbuhan kayu apu meningkatkan nilai $\mathrm{pH}$ limbah radioaktif cair torium melalui mekanisme serupa dengan proses pelepasan $\mathrm{CO}_{2}$ dari air laut. Senyawa karbondioksida dalam air laut terdapat dalam bentuk ion dan bentuk molekul. Bentuk ion dapat berupa ion bikarbonat $\left(\mathrm{HCO}_{3}{ }^{-}\right)$dan karbonat $\left(\mathrm{CO}_{3}{ }^{2-}\right)$ sedangkan bentuk molekul berupa molekul karbondioksida bebas $\left(\mathrm{CO}_{2}\right)$ dan asam karbonat $\left(\mathrm{H}_{2} \mathrm{CO}_{3}\right)$. Empat bentuk karbon dioksida ini berada dalam keadaan seimbang [25]. Reaksinya keseimbangan (5) ini dapat digambarkan sebagai berikut:

$$
\begin{aligned}
& \stackrel{\mathrm{CO}_{2}}{\quad} \stackrel{\mathbb{1} \Leftrightarrow \mathrm{HCO}_{3}{ }^{-}+\mathrm{H}^{+} \rightleftharpoons \mathrm{CO}_{3}{ }^{2-}+\mathrm{H}^{+}}{\mathrm{H}_{2} \mathrm{CO}_{3}}
\end{aligned}
$$


Apabila $\mathrm{CO}_{2}$ dikeluarkan dari air laut melalui proses fotosintesis oleh tumbuhan maka nilai derajat keasaman $(\mathrm{pH})$ air akan bertambah dan ion bikarbonat akan berubah menjadi ion karbonat seiring dengan meningkatnya nilai $\mathrm{pH}$ [25]. Pada tumbuhan air lainnya, seperti tumbuhan rumput laut, proses fotosintesis melibatkan $\mathrm{CO}_{2}$ bebas jika $\mathrm{pH}$ perairan $<6$. Jika $\mathrm{pH}$ perairan berkisar 610 maka $\mathrm{CO}_{2}$ akan digunakan dalam bentuk bikarbonat $\left(\mathrm{HCO}_{3}{ }^{-}\right)$, sedangkan jika $\mathrm{pH}>10$ maka $\mathrm{CO}_{2}$ akan digunakan dalam bentuk ion bikarbonat $\left(\mathrm{CO}_{3}{ }^{2-}\right)[26]$.

Pada penelitian ini $\mathrm{CO}_{2}$ yang terlibat pada proses fotosintesis tumbuhan kayu apu diduga berupa molekul karbondioksida bebas $\left(\mathrm{CO}_{2}\right)$ dan ion bikarbonat $\left(\mathrm{HCO}_{3}{ }^{-}\right)$karena fitoremediasi berlangsung pada kisaran nilai $\mathrm{pH}$ 3-7. Kenaikan $\mathrm{pH}$ akan diikuti dengan menurunnya kelarutan dari senyawa-senyawa yang bersifat toksisitas pada limbah [27].

Aktivitas fotosintesis tidak akan berjalan baik di bawah suhu $5^{\circ} \mathrm{C}$ dan di atas $50^{\circ} \mathrm{C}$ [23]. Suhu optimum pertumbuhan dari tumbuhan pada proses fitoremediasi berkisar antara $27-30^{\circ} \mathrm{C} \quad$ [23]. Pengukuran suhu dilakukan secara duplo $(\mathrm{n}=2)$ pada reaktor kontrol maupun reaktor uji dan diperoleh nilai Standar Deviasi (SD) sebesar $\pm 0,0707$.

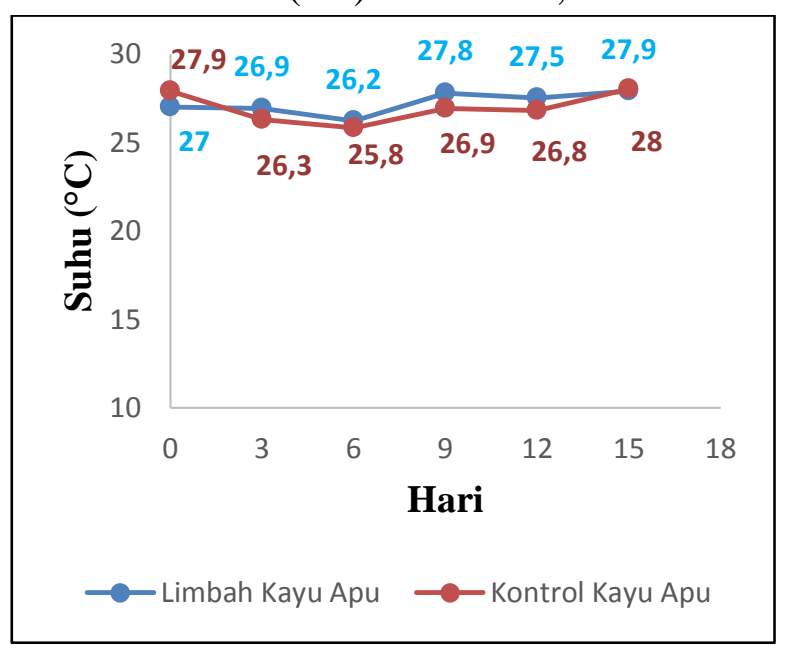

Gambar 4. Perubahan suhu selama proses fitoremediasi menggunakan kayu apu.
Gambar 4 menunjukkan suhu air limbah maupun air sumur (kontrol) pada proses fitoremediasi kayu apu selama 15 hari berkisar antara $26-28^{\circ} \mathrm{C}(\mathrm{SD} \pm 0.0707)$. Suhu secara umum mengalami kenaikan yang fluktuatif. Suhu lingkungan menjadi faktor utama penyebab suhu mengalami kenaikan yang fluktuatif. Perubahan cuaca pada waktu pengukuran suhu juga dapat mempengaruhi nilai suhu dari air limbah tersebut [13].

Suhu air limbah yang dipengaruhi oleh suhu lingkungan akibat perubahan cuaca pada saat perlakuan berpengaruh terhadap tingkat penyerapan kayu apu. Hal ini dikarenakan suhu berpengaruh terhadap proses metabolisme dan fotosintesis. Kenaikan suhu dapat menaikkan kecepatan difusi ion ke akar tanaman sehingga tingkat penyerapan limbah cair oleh tumbuhan menjadi lebih tinggi [28]. Jika suhu mengalami penurunan, maka kelarutan oksigen air dapat mengalami kenaikan sehingga nilai $\mathrm{pH}$ menjadi naik (basa) [22]. Hasil ini relevan dengan mekanisme kenaikan $\mathrm{pH}$ pada pengujian perubahan $\mathrm{pH}$ (Gambar 3).

Biomassa tumbuhan dipengaruhi oleh konsentrasi logam yang menyebabkan terganggunya pertumbuhan tumbuhan sehingga dapat menurunkan produksi biomassa [29]. Pengukuran biomassa dilakukan dengan megetahui bobot kering tumbuhan. Perbedaan variansi nilai dari biomassa tumbuhan kayu apu pada air limbah maupun pada air sumur (kontrol) diketahui dengan uji F (Tabel 4).

Tabel 4. Data hasil uji signifikansi biomassa.

\begin{tabular}{cccccc}
\hline Reaktor & $\mathbf{1}$ & $\mathbf{2}$ & SD & F & $\begin{array}{c}\mathbf{F} \\
\text { Tabel }\end{array}$ \\
\hline Uji & 96,201 & 96,215 & 0,0099 & 1,159 & 647,78 \\
Kontrol & 97,332 & 97,319 & 0,00919 & & \\
\hline
\end{tabular}

Tabel 4 menunjukkan tingkat signifikansi pengujian $(\alpha)$ adalah 0,05 . Penelitian ini 
menggunakan uji $\mathrm{F}$ two-tailed dengan daerah HO berada pada dua sisi. Nilai kritis yang tepat diperoleh dari tabel untuk $\alpha / 2$ sebesar 0,025 dengan derajat kebebasan $v_{\text {maks }}=v_{\min }=$ 1 adalah 647,78. Nilai kritis (F tabel) pada penelitian ini lebih besar dari nilai $\mathrm{F}$ maka $\mathrm{HO}$ diterima (Tabel 4). Oleh karena itu, pada penelitian ini tidak ada perbedaan signifikan dari variansi nilai biomassa tumbuhan kayu apu yang diperoleh pada air limbah maupun pada air sumur (kontrol).

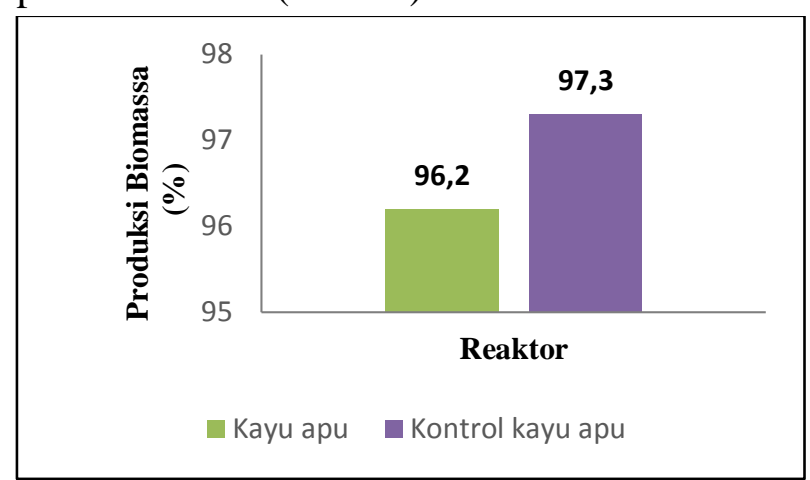

Gambar 5. Produksi biomassa kayu apu pada proses fitoremediasi.

Gambar 5 menunjukkan bahwa biomassa kayu apu menurun dari 97,3\% (SD $\pm 0,009$ ) (b/b) menjadi 96,2\% (SD $\pm 0,009)$ (b/b). Produksi biomassa menurun akibat terganggunya pertumbuhan dari tumbuhan akibat pengaruh logam berat. Logam berat dapat mengganggu proses metabolisme pada tumbuhan yang membantu pembentukan selsel tumbuhan dan jaringan meristem pada akar. Pertumbuhan jaringan pada akar yang menurun dapat mengakibatkan penurunan pertumbuhan bagian tajuk tumbuhan. Penurunan pertumbuhan bagian tajuk tumbuhan mengakibatkan penurunan produksi biomassa tumbuhan [29].

Hal serupa diduga terjadi pada logam radioaktif torium yang mengganggu metabolisme tumbuhan kayu apu. Adanya toksisitas logam menyebabkan tumbuhan sulit memperoleh air karena pengaruh osmotik yang timbul dari kadar larutan yang berlebih, tumbuhan sulit memperoleh hara karena adanya kompetisi antara ion-ion, dan tumbuhan sulit memperoleh $\mathrm{CO}_{2}$, sehingga penerimaan intensitas sinar yang menyebabkan pertumbuhan tumbuhan akan terhambat atau terhenti [22].

\section{Kadar Torium pada Limbah Cair}

Penurunan penyerapan logam pada tumbuhan relatif konstan. Ketika konsentrasi logam dalam limbah cair semakin menurun, maka perubahan fisik pada tumbuhan semakin tampak. Lama waktu pemaparan logam digunakan untuk mengetahui kemampuan optimal tumbuhan dalam melakukan penyerapan [30]. Kadar torium diukur secara duplo $(n=2)$ pada limbah cair selama proses fitoremediasi dan diperoleh standar deviasi sebesar \pm 0.0003 .

Proses fitoremediasi limbah radioaktif cair dengan kayu apu selama 15 hari berhasil menurunkan konsentrasi limbah dari 10 ppm menjadi 0,2582 ppm (Gambar 6) dengan efisiensi remediasi torium oleh kayu apu sebesar 97,4\%. Penurunan menjadi 0 ppm atau mencapai $100 \%$ sebenarnya telah terjadi pada hari ke-3, tetapi konsentrasi kemudian mengalami kenaikan kembali hingga menjadi 0,2582 ppm pada hari ke-15. Pada penelitian ini tumbuhan kayu apu diduga sudah tidak lagi menyerap logam torium secara optimal pada hari ke-6 hingga hari ke-15.

Hasil serupa juga ditunjukkan oleh penelitian fitoremediasi dengan kayu apu pada logam berat lain seperti $\mathrm{Pb}$, tumbuhan kayu apu dapat menyerap limbah yang mengandung logam $\mathrm{Pb}$ dari 2,102 ppm menjadi 1,850 ppm pada hari ke-20. Pada hari ke-15 konsentrasi logam $\mathrm{Pb}$ sudah mencapai 0,000 ppm lalu mengalami kenaikan menjadi 1,850 ppm pada hari ke-20. Hal ini 
disebabkan karena pada ke-15 sampai 20 tumbuhan kayu apu sudah tidak mampu lagi menyerap logam $\mathrm{Pb}$ secara optimal [30].

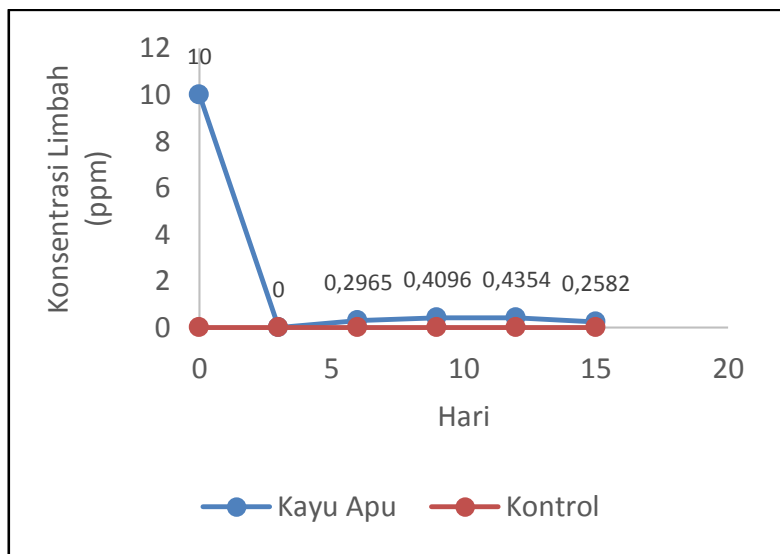

Gambar 6. Penurunan torium pada fitoremediasi dengan kayu apu.

Proses penyerapan zat-zat yang terdapat dalam limbah dilakukan oleh ujung-ujung akar pada tumbuhan melalui jaringan meristem. Proses ini terjadi karena adanya gaya tarik-menarik oleh molekul-molekul air pada tumbuhan. Zat-zat yang telah diserap oleh akar akan masuk ke batang melalui pembuluh pengangkut (xilem) kemudian diteruskan ke daun [31]. Proses pergerakan ion menuju pembuluh xilem pada saat pengangkutan melalui dinding sel dari epidermis ke endodermis. Sebagian ion akan diserap oleh sel-sel yang dilaluinya pada saat proses pengangkutan berlangsung [32].

\section{Kadar Torium pada Tumbuhan}

Hasil penelitian menunjukkan bahwa tumbuhan kayu apu pada reaktor kontrol dengan air sumur tidak mengandung torium, sementara pada reaktor yang terpapar limbah radioaktif cair torium dengan konsentrasi 10 ppm, terjadi akumulasi Th pada kayu apu sebesar 4.069,4 mg/kg berat kering (Tabel 5).

Proses fitoremediasi dengan tumbuhan air lainnya seperti eceng gondok pada limbah dengan konsentrasi logam $\mathrm{Cu}$ sebesar 1,05 ppm menghasilkan akumulasi logam pada batang sebesar 2.314,2 mg/kg (berat kering). Logam lain seperti Cd yang sebesar 0,8 ppm dalam limbah mampu terakumulasi pada akar sebesar 230,39 mg/kg (berat kering) [33]. Dengan demikian, tumbuhan menyerap logam lalu logam mengalami akumulasi pada bagian tumbuhan.

Tabel 5. Kadar torium pada kayu apu.

\begin{tabular}{ccc}
\hline No & Tumbuhan & $\begin{array}{c}\text { Kadar Torium } \\
(\mathbf{m g} / \mathbf{k g})\end{array}$ \\
\hline 1 & Kontrol Kayu Apu & 0,0 \\
2 & Kayu Apu & $4.069,4$ \\
\hline
\end{tabular}

Fenomena ini pada satu sisi tampaknya akan dapat diterima apabila jumlah torium yang diserap oleh tumbuhan sebanding (linear) dengan konsentrasi torium dalam air namun terdapat penyimpangan dari ketergantungan linear radionuklida konsentrasi rendah dalam medium air. Kondisi ini ditandai dengan radionuklida yang biasanya menunjukkan peningkatan adsorpsi. Meskipun secara umum diasumsikan bahwa pergerakan torium melalui jaringan tanaman dibatasi oleh adsorpsi ke dinding sel, pada penelitian ini peningkatan mobilitas dan bioavailabilitas torium terjadi akibat proses kompleksasi dan pengkelatan tertentu [34].

Dinding sel tumbuhan diketahui memiliki muatan negatif karena pengaturan gugus protein karboksil dan fosfat. Torium juga menunjukkan kecenderungan kuat untuk membentuk kompleks dengan asam organik. Tarikan elektrostatik antara gugus fungsi yang diisi dan terikat secara organik dengan torium menyebabkan peningkatan laju transpor torium yang melintasi membran lipid sel. Peningkatan permeabilitas membran kemudian menyebabkan peningkatan akumulasi torium pada akar dan daun tumbuhan [34]. 


\section{Radioaktivitas dalam Limbah Cair}

Kemampuan tumbuhan dalam menurunkan radioaktivitas pada limbah cair dipengaruhi oleh dinamika proses dalam tumbuhan. Mekanisme yang terjadi pada akar tumbuhan yang dibantu oleh agen chelating, perubahan $\mathrm{pH}$ yang diinduksi tumbuhan, dan reaksi redoks, dapat membuat tumbuhan melarutkan dan mengambil zat gizi mikro dari tingkat yang sangat rendah di tanah [35]. Mekanisme seperti penyerapan, translokasi, dan penyimpanan unsur-unsur beracun diduga terjadi pada proses akumulasi logam radioaktif torium.

Hasil pengukuran menunjukkan bahwa radioaktivitas air sumur pada reaktor kontrol sebelum dan sesudah fotoremediasi adalah sebesar $0,000 \mathrm{~Bq} / \mathrm{L}$, sementara nilai radioaktivitas limbah cair pada reaktor uji mengalami penurunan setelah proses fitoremediasi.

Tumbuhan kayu apu dapat menurunkan radioaktivitas limbah cair sebesar 77,619\%. Nilai radioaktivitas limbah cair turun menjadi $0,631 \mathrm{~Bq} / \mathrm{L}$ dari nilai radioaktivitas awal sebesar 2,819 Bq/L (Gambar 7). Nilai radioaktivitas hasil penelitian ini telah mencapai nilai di bawah tingkat klierens yang mengacu pada Perka Bapeten No.16 Tahun 2012 tentang Tingkat Klierens yaitu sebesar 1 $\mathrm{Bq} / \mathrm{L}$. Oleh karena itu limbah cair yang telah mengalami proses fitoremediasi dengan menggunakan kayu apu dapat dilepaskan langsung ke badan air penerima seperti sungai, danau, waduk, dan lain-lain [36].

Penurunan radioaktivitas terjadi seiring dengan adanya penyerapan torium dalam tumbuhan kayu apu. Penyerapan torium oleh tumbuhan kayu apu disebut juga fitoakumulasi yang merupakan salah satu jenis fitoremediasi. Fitoakumulasi adalah proses penyerapan polutan logam, termasuk logam radioaktif seperti torium, oleh akar tumbuhan dan mengakumulasikannya ke bagian tumbuhan, seperti akar, batang, atau daun. Proses fitoakumulasi juga telah dilaporkan dapat menyebabkan dekontaminasi logam dengan baik pada unsur seperti Sr-90, Cs-137, Pu-239, U-238, dan U234 [37].

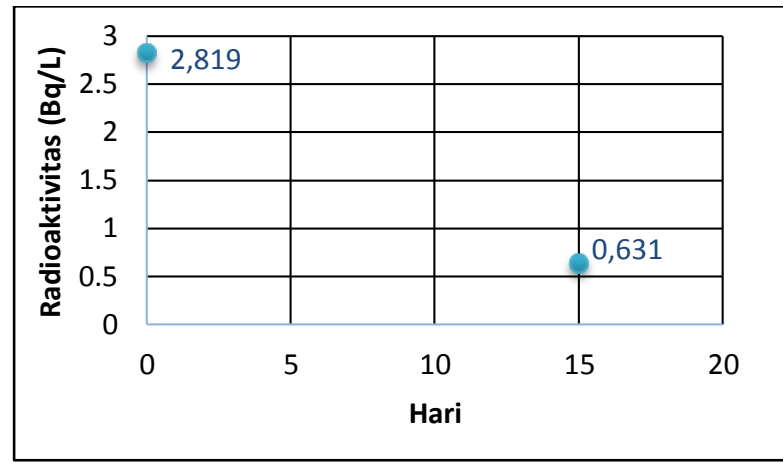

Gambar 7. Penurunan radioaktivitas limbah radioaktif cair torium.

Pengolahan limbah radioaktif cair dengan metode koagulasi menggunakan koagulan yaitu fero sulfat dengan dosis $225 \mathrm{mg} / \mathrm{L}$ dan $\mathrm{pH} \quad 8,0$ dapat menurunkan radioaktivitas hingga $100 \%$ [3]. Kemampuan metode koagulasi dalam menurunkan nilai radioaktivitas lebih baik dibandingkan fitoremediasi namun fitoremediasi dengan kayu apu memiliki keunggulan lebih ramah lingkungan dibandingkan dengan koagulan kimia.

\section{KESIMPULAN}

Fitoremediasi dengan tumbuhan kayu apu memiliki nilai efisiensi remediasi sebesar 97,4\% dan mampu menurunkan kadar torium dari konsentrasi awal 10 ppm menjadi 0,2582 ppm selama 15 hari waktu pemaparan dengan penurunan signifikan pada 3 hari pemaparan. Tumbuhan kayu apu dapat menurunkan radioaktivitas limbah cair sebesar 77,619\%. Nilai radiaoktivitas limbah cair turun menjadi 
0,631 $\mathrm{Bq} / \mathrm{L}$ dari nilai radioaktivitas awal sebesar 2,819 Bq/L. Nilai radioaktivitas tersebut sudah dibawah Tingkat Klierens sehingga limbah radioaktif cair setelah fitoremediasi dapat dilepaskan langsung dengan aman ke lingkungan.

\section{UCAPAN TERIMA KASIH}

Terima kasih kepada PTBGN yang telah memberikan kesempatan untuk melakukan penelitian sebagai salah satu syarat memperoleh gelar Sarjana Sains di UIN Syarif Hidayatullah Jakarta.

\section{DAFTAR PUSTAKA}

[1] Aisyah, "Pengelolaan Pradisposal Limbah Pabrik Kaos Lampu Petromaks yang Mengandung Torium", Jurnal Forum Nuklir, 6(2), 135-144, 2012.

[2] PUSDIKLAT BATAN, Prinsip Dasar Pengukuran Radiasi - Modul Pusdiklat Badan Tenaga Nuklir Nasional. Jakarta: PUSDIKLAT BATAN, 2015.

[3] D. P. Marisi, Suprihatin, dan A. Ismayana, "Penurunan Kadar Torium dan Radioaktivitas dalam Limbah Cair Proses Pengolahan Monasit PLUTHO Menggunakan Koagulan $\mathrm{FeSO}_{4} "$, Eksplorium, 39(1), 39-50, 2018.

[4] H. Martono, dan T. Las, "Penyerapan Uranium dengan Resin Penukar Anion dan Imobilisasi Menggunakan Polimer", Prosidiing Seminar Nasional Teknologi Pengelolaan Limbah VIII, 111-118, 2010.

[5] R. Kamaraj, and S. Vasudevan, "Evaluation of electrocoagulation process for the removal of strontium and cesium from aqueous solution", Chemical Engineering Research and Design, 19, 2014.

[6] R. Irawanto, "Fitoremediasi Lingkungan dalam Taman Bali". Local Wisdom, 2(4), 29-35, 2010.

[7] D. D. Santriyana, R. Hayati, dan I. Apriani, "Eksplorasi Tanaman Fitoremediator Alumunium (Al) yang ditumbuhkan pada Limbah IPA PDAM Tirta Khatulistiwa Kota Pontianak", Jurnal Teknologi Lingkungan Lahan Basah, 1(1), 1-11, 2013.

[8] N. Hidayati, "Mekanisme Fisiologis Tumbuhan Hiperakumulator Logam Berat", Jurnal Teknik
Lingkungan, 14(2), 75-82, 2013.

[9] F. Baroroh, E. Handayanto, dan R. Irawanto, "Fitoremediasi Air Tercemar $(\mathrm{Cu})$ Menggunakan Salvinia molesta dan Pistia stratiotes serta Pengaruhnya terhadap Pertumbuhan Tanaman Brassica rapa", Jurnal Tanah Dan Sumberdaya Lahan, 5(1), 689-700, 2018.

[10] S. Hapsari, B. Zaman, dan P. Andarani, "Kemampuan Tumbuhan Kayu Apu (Pistia Stratiotes L.) dalam Menyisihkan Kromium Total (Cr-T) dan COD Limbah Elektroplating", Jurnal Teknik Lingkungan, 5(4), 1-9, 2016.

[11] M. Khasanah, A. D. Moelyaningrum, dan R. S. Pujiati, "Analisis Perbedaan Tanaman Kayu Apu (Pistia stratiotes) sebagai Fitoremediasi Merkuri (Hg) pada Air", Jurnal Kesehatan Lingkungan, 9(3), 105-110, 2018.

[12] R. I. Laksmana. Standar Operasional Prosedur Pembuatan Larutan Induk Thorium. Jakarta: Pusat Teknologi Bahan Galian Nuklir BATAN, 2018a.

[13] A. E. Nurfita, E. Kurniati, dan A. T. S. Haji, "Efisiensi Removal Fosfat pada Pengolahan Limbah Cair Laundry dengan Fitoremediasi Kiambang (Salvinia natans)", Jurnal Sumberdaya Alam Dan Lingkungan, 18-26, 2017.

[14] R. I. Laksmana, Standar Operasional Prosedur Pengukuran Radioaktivitas Thorium. Jakarta: Pusat Teknologi Bahan Galian Nuklir BATAN, 2018b.

[15] J. Caroline J, dan G. A. Moa, "Fitoremediasi Logam Timbal $(\mathrm{Pb})$ Menggunakan Tanaman Melati Air (Echinodorus palaefolius) pada Limbah Industri Peleburan Tembaga dan Kuningan", Seminar Nasional Sains Dan Teknologi Terapan III, 733-744, 2015.

[16] Sumiarti, dan Alwi, Standar Operasional Prosedur Penetapan Thorium dengan Metode Spektrofotometri. Jakarta: Pusat Teknologi Bahan Galian Nuklir BATAN, 2018.

[17] SNI 13-6793-2002 tentang Metode Pengujian Kadar Air, Kadar Abu, dan Bahan Organik dari Tanah Gambut dan Tanah Organik Lainnya. (2002). Jakarta: Badan Standar Nasional.

[18] M. O. Damanik, dan I. F. Purwati IF, "Range Finding Test (RFT) Cyperus rotundus L. dan Scirpus grossus sebagai Penelitian Pendahuluan dalam Pengolahan Limbah Cair Tempe", Jurnal Teknis ITS, 7(1), 5-8, 2018.

[19] D. P. Raras, B. Yusuf, dan Alimuddin, "Analisis 
Kandungan Ion Logam Berat (Fe , Cd , Cu dan $\mathrm{Pb}$ ) pada Tanaman Apu-Apu (Pistia Stratiotes L) dengan menggunakan Variasi Waktu", Prosiding Seminar Tugas Akhir FMIPA UNMUL, 2015.

[20] Nurlina, S. Suhadiyah, dan M. R. Umar, "Akumulasi Logam Berat Besi (Fe) Pada Kiapu Pistia stratiotes L. dari Air Sumur Sekitar Workshop Unhas", Prosiding Seminar Nasional From Basic Science to Comprehensive Education, 151-155, 2016.

[21] H. M. Saleh, "Water hyacinth for phytoremediation of radioactive waste simulate contaminated with cesium and cobalt radionuclides", Nuclear Engineering and Design, 242, 425-432, 2012.

[22] M. Haryati, T. Purnomo, dan S. Kuntjoro, "Kemampuan Tanaman Genjer (Limnocharis Flava (L.) Buch) Menyerap Logam Berat Timbal ( $\mathrm{Pb}$ ) Limbah Cair Kertas pada Biomassa dan Waktu Pemaparan Yang Berbeda", Jurnal Lentera Bio, 1(3), 131-138, 2012.

[23] C. Novi, Sartika, dan A. N. Shobah, "Fitoremediasi Logam Seng (Zn) Menggunakan Hydrilla sp. Pada Limbah Industri Kertas", Jurnal Kimia Valensi, 5(1), 108-114, 2019.

[24] E. Suryati, H. Triana, U. Widyastuti, A. Tenriulo, "Regenerasi dan Perbanyakan Rumput Laut Kappaphycus alvarezii Hasil Transformasi Gen Superoksida Dismutase (MaSOD)", Jurnal Riset Akuakultur, 11(129), 321-330, 2016.

[25] T. Susana, "Karbondioksida", Oseana, XIII(1), 1-11, 1988.

[26] N. Sa'adah, dan S. Widyaningsih, "Pengaruh Pemberian $\mathrm{CO}_{2}$ terhadap $\mathrm{pH}$ Air pada Pertumbuhan Caulerpa racemosa var. uvifera", Jurnal Kelautan Tropis, 21(1), 17-22, 2018.

[27] D. S. Vidyawati, dan H. Fitrihidajati, "Pengaruh Fitoremediasi Eceng Gondok (Eichornia crassipes) melalui Pengenceran terhadap Kualitas Limbah Cair Industri Tahu", Jurnal Lentera Bio, 8(2), 113-119, 2019.

[28] Z. Oktavia Z, Budiyono, dan N. A. Y. Dewanti, "Pengaruh Variasi Lama Kontak Fitoremediasi Tanaman Kiambang (Salvinia Molesta) terhadap Kadar Kadmium (Cd) pada Limbah Cair Home Industry Batik "X" Magelang", Jurnal
Kesehatan Masyarakat, 4(5), 238-246, 2016.

[29] L. K. O. Serang, E. Handayanto, dan R. Rindyastuti, "Fitoremediasi Air Tercemar Logam Kromium dengan Menggunakan Sagittaria lancifolia dan Pistia stratiotes Serta Pengaruhnya Terhadap Pertumbuhan Kangkung (Ipomea reptans)", Jurnal Tanah Dan Sumberdaya Lahan, 5(1), 739-746, 2018.

[30] Y. A. Dieta, dan N. Hendrasarie, "Kemampuan Adsorpsi $\mathrm{Pb}$ dari Limbah Industri oleh Tumbuhan Kayu Ambang (Lemna minor), Kayu Apu (Pistia stratiotes), dan Eceng Gondok (Eichornia crassipes solm)", Jurnal Envirotek, 11(1), 39-45, 2019.

[31] N. Hardyanti, dan S. S. Rahayu, "Fitoremediasi Phospat dengan Pemanfaatan Eceng Gondok (Eichornia crassipes) (Studi Kasus pada Limbah Cair Industri Kecil Laundry) ", Jurnal Presipitasi : Media Komunikasi Dan Pengembangan Teknik Lingkungan, 2(1), 28-33, 2001.

[32] Y. Guntur, "Proses Bioremediasi Limbah Rumah Tangga Dalam Skala Kecil Dengan Kemampuan Tanaman Air Pada Sistem Simulasi", Skripsi Insitut Pertanian Bogor, 2001.

[33] G. Swain, S. Adhikari, and P. Mohanty, "Phytoremediation of Copper and Cadmium from Water Using Water Hyacinth, Eichhornia crassipes", Internasional Journal Of Agricultural Science and Technology, 2(1), 1-7, 2014.

[34] I. Shtangeeva, and A. Sophie, "Phytoextraction of Thorium from Soil and Water Media", Water Air and Soil Pollution, 154, 19-35, 2004.

[35] B. V. Tangahu, S. Rozaimah, S. Abdullah, H. Basri, M. Idris, N Anuar, M. Mukhlisin, "A Review on Heavy Metals (As , $\mathrm{Pb}$, and $\mathrm{Hg}$ ) Uptake by Plants through Phytoremediation", International Journal of Chemical Engineering, 1-30, 2011.

[36] Peraturan Kepala Badan Pengawas Tenaga Nuklir Nomor 16 Tahun 2012 tentang Tingkat Klierens. (2012). Jakarta: Badan Pengawas Tenaga Nuklir (BAPETEN).

[37] F. Nur, "Fitoremediasi Logam Berat Kadmium (Cd)", Biogenesis, 1(1), 74-83, 2013. 